\title{
Exercise-induced anaphylaxis unrelated to food ingestion and with hyperleukotrieneuria during challenge testing
}

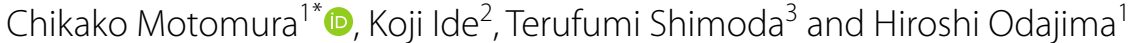

\begin{abstract}
Background: Exercise-induced anaphylaxis (EIA) is a rare and potentially life-threatening disorder that can develop independently without food ingestion. Cold drinks can also trigger symptoms in some patients with cold-induced anaphylaxis. We present a case of a patient with EIA that was diagnosed on the basis of positive exercise loading test with hyperleukotrieneuria.

Case presentation: A 12-year-old girl presented with acute flushing, cyanosis, swollen eyelids, and dyspnea after an endurance run in winter or swimming in a cold-water pool. She also developed dyspnea after having a cold drink. She had no history of food allergies, atopy, or asthma. No association was noted between anaphylaxis and food intake in her history. On the first day, she ingested $200 \mathrm{~mL}$ of $5^{\circ} \mathrm{C}$ cold water in $30 \mathrm{~s}$, which did not trigger symptomatic responses, but her urinary leukotriene E4 (LTE4) level increased (pre-challenge test: 295 pg/mg-creatinine (cr), postchallenge test: $400 \mathrm{pg} / \mathrm{mg}$-cr). On the second day, she underwent the exercise loading test according to the Bruce protocol by using an ergometer to increase the power of exercise every $2 \mathrm{~min}$. She had been fasting for $>15 \mathrm{~h}$ and did not have breakfast. Just after the exercise loading test, the plasma adrenaline and noradrenaline increased. At $15 \mathrm{~min}$ after the exercise loading test, her plasma adrenaline and histamine (pre-challenge test: $0.7 \mathrm{ng} / \mathrm{mL}, 15 \mathrm{~min}$ post-challenge test: $81 \mathrm{ng} / \mathrm{mL}$ ) rose sharply with anaphylaxis symptoms accompanied by increasing urinary LTE4 (prechallenge test: $579 \mathrm{pg} / \mathrm{mg}$-cr, post-challenge test: $846 \mathrm{pg} / \mathrm{mg}-\mathrm{cr}$ ). After she was discharged, she was restricted from strenuous exercise especially in cold environments and prescribed an adrenaline autoinjector.
\end{abstract}

Conclusion: Cold stimulation can become a co-effector of EIA. Measurements of urinary LTE4 levels during challenge testing are useful for diagnosing ElA and capture the pre-anaphylaxis stage.

Keywords: Exercise-induced anaphylaxis, Urinary leukotriene E4, Cold-induced anaphylaxis, Pre-anaphylaxis stage, Mast cell activation

\section{Background}

Exercise-induced anaphylaxis (EIA) is a potentially lifethreatening disorder that can develop independently or in combination with food ingestion as food-dependent

\footnotetext{
*Correspondence: chikako.m31@gmail.com

${ }^{1}$ Department of Pediatrics, National Hospital Organization Fukuoka

National Hospital, 4-39-1 Yakatabaru, Minamiku, Fukuoka city, Fukuoka 811-1394, Japan

Full list of author information is available at the end of the article
}

EIA (FDEIA). EIA without food ingestion is rare; few studies have reported positive challenge test results with elevated objective marker levels in patients with EIA [1]. Cold drinks can also trigger symptoms in some patients with cold-induced anaphylaxis.

Conversely, mast cells may play a role in cysteinyl leukotriene (CysLT) generation during anaphylactic reactions [2]. Urinary leukotriene E4 (LTE4) is the most reliable analytic parameter for monitoring endogenous CysLT synthesis. We herein present a case of a patient original author(s) and the source, provide a link to the Creative Commons licence, and indicate if changes were made. The images or other third party material in this article are included in the article's Creative Commons licence, unless indicated otherwise in a credit line to the material. If material is not included in the article's Creative Commons licence and your intended use is not permitted by statutory regulation or exceeds the permitted use, you will need to obtain permission directly from the copyright holder. To view a copy of this licence, visit http://creativecommons.org/licenses/by/4.0/. The Creative Commons Public Domain Dedication waiver (http://creativeco mmons.org/publicdomain/zero/1.0/) applies to the data made available in this article, unless otherwise stated in a credit line to the data. 
with EIA that was diagnosed on the basis of positive exercise loading test with hyperleukotrieneuria.

\section{Case presentation}

A 12-year-old girl presented with acute flushing, cyanosis, swollen eyelids, urticaria, and dyspnea experience after an endurance run in winter or swimming in a cold-water pool. She also developed dyspnea after having a cold drink. She had no history of food allergies, atopy, or asthma. No association was noted between anaphylaxis and food intake in her history.

Laboratory assessment during the asymptomatic period revealed the absence of peripheral eosinophilia (white blood cell count, $5150 / \mu \mathrm{L}$ with $2 \%$ eosinophils) and a total immunoglobulin (Ig) E level of $1255 \mathrm{IU} / \mathrm{mL}$. Specific quantitative $\mathrm{IgE}$ testing with $\mathrm{ImmunoCAP}^{\circledR}$ $>0.7 \mathrm{UA} / \mathrm{mL}$ for house dust, dermatophagoides, cedar pollen, and cat dander and negative for wheat, shrimp, and crab. The skin-prick test also was negative for wheat, shrimp, and crab. On the basis of the symptomatic episode, she underwent a 2-day challenge test to measure urinary LTE4 levels before and $3 \mathrm{~h}$ after the test. Urinary LTE4 was quantified by using a commercial enzyme immunoassay kit (Cayman) after purification by highperformance liquid chromatography.

On the first day, she was asked to ingest $200 \mathrm{~mL}$ of cold water at a temperature of $5{ }^{\circ} \mathrm{C}$ in $30 \mathrm{~s}$, which did not trigger any symptomatic responses. After the challenge test, the plasma catecholamine (adrenaline, noradrenaline, and dopamine) and histamine levels did not significantly alter (Fig. 1a and b), but her urinary LTE4 level increased (Fig. 1c, pre-challenge test 295 pg/ mg-creatinine (cr), post-challenge test $400 \mathrm{pg} / \mathrm{mg}$-cr). On the second day, she underwent the exercise loading test according to the Bruce protocol [3] by using an ergometer to increase the power of exercise every $2 \mathrm{~min}$. She had been fasting for $>15 \mathrm{~h}$ and did not have breakfast. She developed acute flushing, cyanosis, swollen eyelids, dyspnea, and hypotension when the maximum loading reached 80 watts. Just after the exercise loading test, her plasma adrenaline and noradrenaline increased (Fig. 2a). At $15 \mathrm{~min}$. after the exercise loading test, her plasma adrenaline and histamine (Fig. 2b, pre-challenge test: $0.7 \mathrm{ng} / \mathrm{mL}, 15 \mathrm{~min}$ post-challenge test: $81 \mathrm{ng} / \mathrm{mL}$ ) rose sharply with anaphylaxis symptoms, such as cyanosis, dyspnea, and hypotension. Those symptoms were accompanied by increasing urinary LTE4 (Fig. 2c, prechallenge test: $579 \mathrm{pg} / \mathrm{mg}$-cr, post-challenge test: $846 \mathrm{pg} /$ mg-cr).

The diagnosis of EIA had to be distinguished from systemic mastocytosis, exercise associated laryngoesophageal reflux, cardiovascular disorders, cholinergic urticarial, and hypoglycemia. The episode was

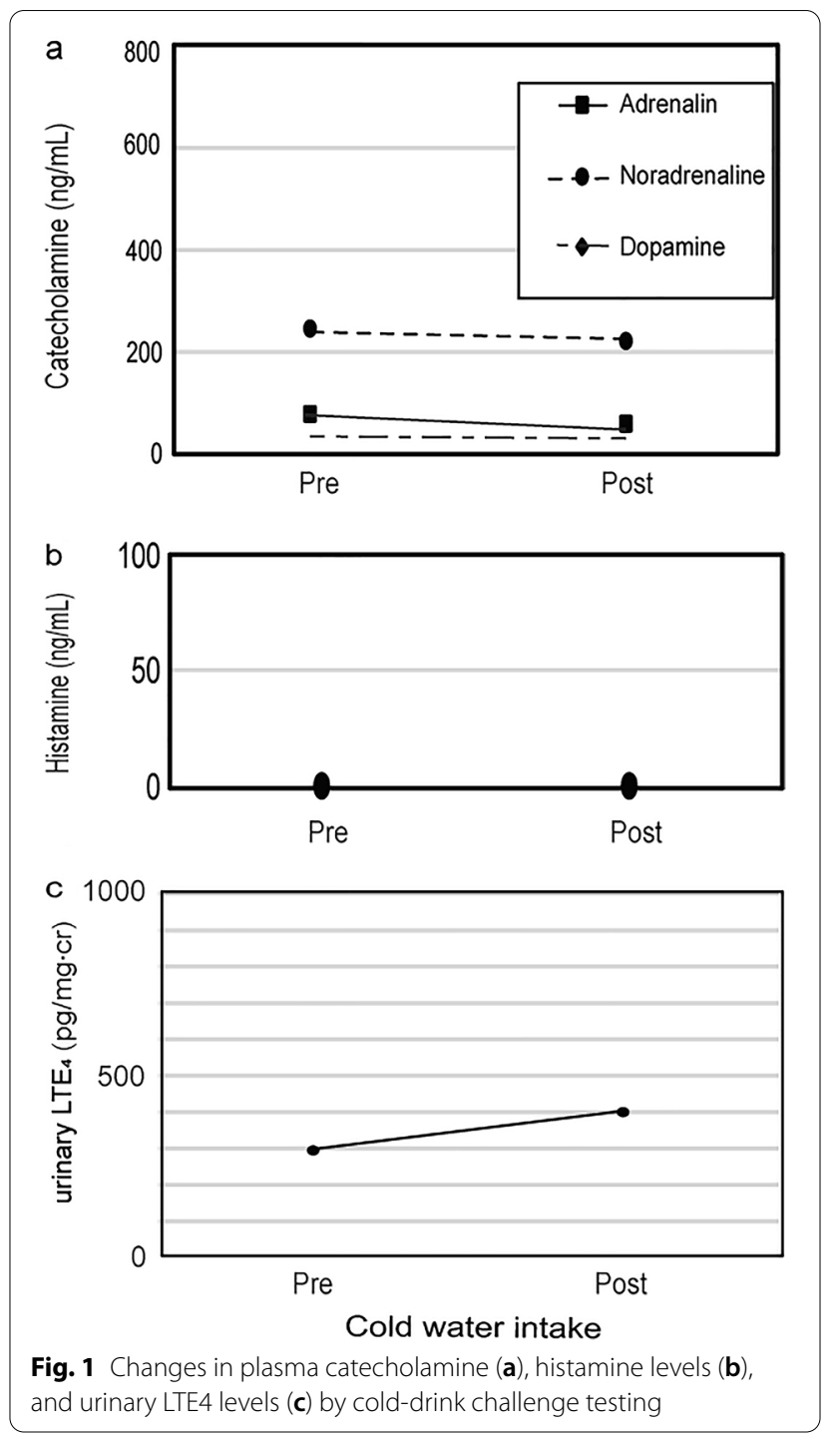

confirmed to be EIA that was diagnosed on the basis of positive exercise loading test with hyperleukotrieneuria. Her serum tryptase level was $1.3 \mu \mathrm{g} / \mathrm{L}$, within the normal range when she was asymptomatic.

After challenge testing, the patient was treated with anti-LT receptor antagonists. During next hospitalization, to improve her quality of life related to exercise, training by exercise prescription was conducted. Two weeks later, she increased the exercise intensity without anaphylaxis. After she was discharged, she was restricted from strenuous exercise especially in cold environments and prescribed an adrenaline autoinjector. 

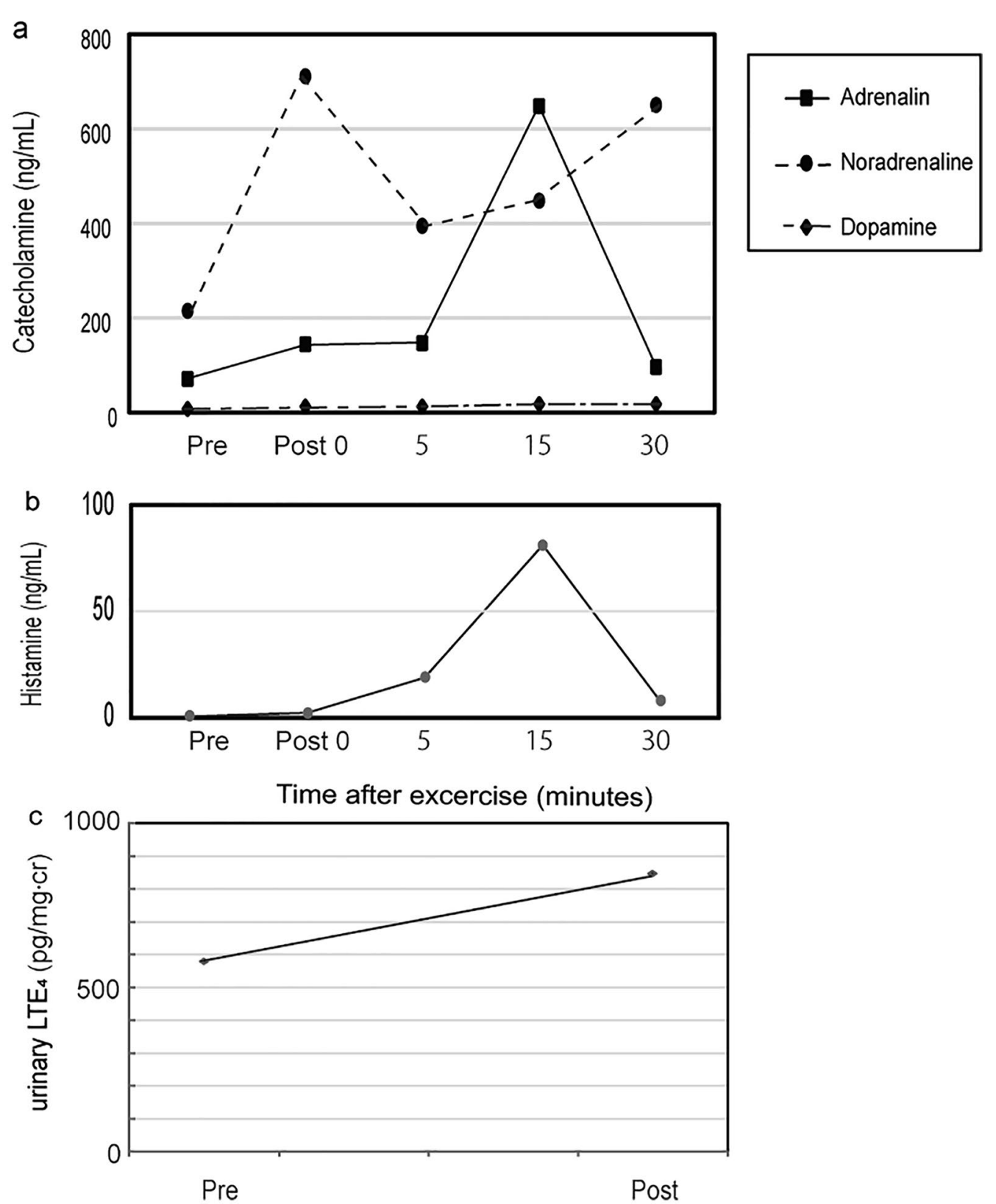

Fig. 2 Changes in plasma catecholamine (a), histamine levels (b), and urinary LTE4 levels (c) by the exercise loading test

\section{Discussion and conclusions}

In this case, anaphylaxis with hypotension developed after exercise without food intake and was accompanied by elevated levels of plasma histamine and urinary LTE4, both of which are clinical markers of mast cell activation [4]. Histamine is immediately released by mast cell degranulation that is activated by C3a and others. Plasma histamine levels were reported to be elevated in patients with FDEIA who had a positive challenge test [5]. Conversely, CysLT is derived from mast cell membranes within minutes, and urinary LTE4 levels increase by about tenfold from baseline after a positive challenge test in anaphylactic patients [2]. For other allergic and inflammatory disease, the urinary LTE4 increased in atopic patients after allergen inhalation and patients with eosinophilic vasculitis [6]. In both aspirin-intolerant asthma and aspirin-tolerant asthma patients, urinary LTE4 decreased after the sinus surgery. Recent studies have shown that the change in tryptase from baseline may be a more valuable parameter for diagnosing 
anaphylaxis [7]. We did not measure the change in tryptase during provocation testing in this case. Systemic mastocytosis was denied because the baseline tryptase was in the normal range.

The mechanism underlying EIA, especially when not caused by specific food exposure, has not been completely elucidated; however, several hypotheses have been proposed. First, reduced cellular $\mathrm{pH}$ in lactic acidosis due to supramaximal exercise was proposed as a way that could promote mast cell degradation and increase the propensity toward anaphylaxis [8]. Second, mild-to-severe exercise alters blood flow distribution, with a greater percentage of cardiac output going to active tissues such as skeletal muscle accompanied by a reduction in blood flow to the visceral organs, primarily the stomach and intestines. Functional heterogeneity has been demonstrated in human mast cells from different tissues. Therefore, the quantity and spectrum of mediators released may differ across different locations as well as under different situations [9]. These hypotheses warrant further investigation by comparing EIA patients with healthy controls.

Notably, urinary LTE4 levels reportedly did not increase after exercise in healthy children [10]. The urinary LTE4 level in our patient increased in both exercise loading and cold stimulation despite the negative result with coldwater intake; in the past, the patient had developed coldinduced anaphylaxis with urticaria while swimming in a pool. Generally, both mast cell and recruited basophils release histamine and other inflammatory mediators (prostaglandins, leukotrienes, and cytokines), leading to the activation of urticarial lesions. The same mechanism occurs systemically during cold-induced anaphylaxis. Interestingly, a study reported two patients with FDEIA who developed symptoms induced by physical exercise at cold temperatures [11]. However, the rate of anaphylactic reactions induced by cold stimulation in patients with EIA or FDEIA is unknown.

Our patient may have developed EIA. We found that plasma histamine levels transiently increased after exercise loading in this patient; however, this increase was not observed after the cold-water intake challenge test and was without symptoms. Stringent criteria in selecting subjects as well as performing repeated provocation tests might be needed to detect transiently increased histamine levels, even in FDEIA provocation tests [5]. Given that cold-water intake stimulation specifically to the throat mildly activates mast cells and basophils, we could knew the pre-anaphylaxis stage to measure the elevated urinary LTE4 level even without any symptoms present.

There have been some reports of successfully using anti-IgE biologics to treat EIA [1] and cold-induced anaphylaxis [12]. The mechanism by which non-specific IgE-dependent mast cell activation can be provoked by exercise, cold stimulation, or both in such cases is unclear. The established efficacy of anti-IgE biologics in the treatment of allergic asthma and allergic rhinitis putatively reflects the depletion of free IgE from serum and tissue, ultimately leading to reduced binding of IgE to its high-affinity surface receptor FceRI. Because the occupancy of FceRI by IgE determines the levels of surface FceRI expression, this leads to a rapid depletion of both cell-bound IgE and surface FceRI expression on blood basophils and a more gradual depletion of these proteins from skin and other organs' mast cells [13].

We believe that cold stimulation can be a co-effector for EIA. Measurements of urinary LTE4 levels during challenge testing were useful for diagnosing EIA. The change in urinary LTE4 from baseline might be sufficiently sensitive to capture the pre-anaphylaxis stage at which provocation tests do not induce symptoms. In the future, conducting studies to elucidate the mechanism of non-specific IgE-mediated activation of mast cells, which can drive allergic reactions in patients with anaphylaxis induced by both exercise and cold stimulation, would be beneficial to further our understanding of these mechanisms and potentially improve management.

\section{Abbreviations \\ EIA: Exercise-induced anaphylaxis; FDEIA: Food-dependent EIA; CysLT: Cysteinyl leukotriene (CysLT.}

\section{Acknowledgements}

Not applicable.

\section{Authors' contributions}

$\mathrm{CM}$ and $\mathrm{Kl}$ assessed the patient and performed the provocation tests in hospital. AS and $\mathrm{HO}$ helped review the manuscript. CM conducted most of the literature review and writing of the manuscript. All authors read and approved the final manuscript.

\section{Funding}

None.

\section{Declarations}

Ethics approval and consent to participate

This report was approved by the Ethics Board of the National Hospital Organization Fukuoka National Hospital (No. F2-40).

\section{Consent for publication}

Consent for publication was obtained from the patient.

Competing interests

The authors declare that they have no competing interests.

Author details

${ }^{1}$ Department of Pediatrics, National Hospital Organization Fukuoka National Hospital, 4-39-1 Yakatabaru, Minamiku, Fukuoka city, Fukuoka 811-1394, Japan. ${ }^{2}$ Ide Kid's Allergy Clinic, 3-32-19 Yokote, Minamiku, Fukuoka 811-1311, Japan. ${ }^{3}$ Department of Clinical Research, National Hospital Organization 
Fukuoka National Hospital, 4-39-1 Yakatabaru, Minamiku, Fukuoka 811-1394, Japan.

Received: 27 November 2020 Accepted: 27 August 2021

Published online: 08 September 2021

\section{References}

1. Christensen MJ, Bindslev-Jensen C. Successful treatment with omalizumab in challenge confirmed exercise-induced anaphylaxis. J Allergy Clin Immunol Pract. 2017;5:204-6.

2. Ono $\mathrm{E}$, Taniguchi M, Mita H, et al. Increased production of cysteinyl leukotrienes and prostaglandin D2 during human anaphylaxis. Clin Exp Allergy. 2009;39:72-80.

3. Fletcher GF, Balady GJ, Amsterdam EA, et al. Exercise standards for testing and training: a statement for healthcare professionals from the American Heart Association. Circulation. 2001;104:1694-740.

4. Akin C. Mast cell activation syndromes. J Allergy Clin Immunol. 2017;140:349-55

5. Aihara Y, Takahashi Y, Kotoyori T, et al. Frequency of food-dependent, exercise-induced anaphylaxis in Japanese junior-high-school students. J Allergy Clin Immunol. 2001;108:1035-9.

6. Lieberman JA, Bingemann TA, Wang J. Diagnostic challenges in anaphylaxis. J Allergy Clin Immunol Pract. 2020;8:1177-84.
7. Taniguchi M, Higashi N, Ono E, Mita H, Akiyama K. Hyperleukotrieneuria in patients with allergic and inflammatory disease. Allergol Int. 2008:57(4):313-20

8. Wasserman K, Cox TA, Sietsema KE. Ventilatory regulation of arterial $\mathrm{H}(+)$ (pH) during exercise. Respir Physiol Neurobiol. 2014;190:142-8.

9. Galli SJ, Kalesnikoff J, Grimbaldeston MA, et al. Mast cells as "tunable" effector and immunoregulatory cells: recent advances. Annu Rev Immunol. 2005;23:749-86.

10. Kikawa Y, Miyanomae T, Inoue Y, et al. Urinary leukotriene E4 after exercise challenge in children with asthma. J Allergy Clin Immunol. 1992:89:1111-9.

11. Pravettoni $\vee$, Incorvaia $C$. Diagnosis of exercise-induced anaphylaxis: current insights. J Asthma Allergy. 2016;9:191-8.

12. Boyce JA. Successful treatment of cold-induced urticaria/anaphylaxis with anti-IgE. J Allergy Clin Immunol. 2006;117:1415-8.

13. Beck LA, Marcotte GV, MacGlashan D, et al. Omalizumab-induced reductions in mast cell Fce psilon RI expression and function. J Allergy Clin Immunol. 2004;114:527-30.

\section{Publisher's Note}

Springer Nature remains neutral with regard to jurisdictional claims in published maps and institutional affiliations.
Ready to submit your research? Choose BMC and benefit from:

- fast, convenient online submission

- thorough peer review by experienced researchers in your field

- rapid publication on acceptance

- support for research data, including large and complex data types

- gold Open Access which fosters wider collaboration and increased citations

- maximum visibility for your research: over 100M website views per year

At BMC, research is always in progress.

Learn more biomedcentral.com/submissions 